\title{
EUROPEAN ONLINE MARKETPLACE - NEW MEASURES FOR CONSUMER PROTECTION AGAINST “OLD CONFLICT OF LAWS RULES”
}

by

AGATA JAROSZEK

The paper aims at discussing the rationale for protecting consumers under the new directive on consumer rights (CRD) and its relation to conflict of law rules under the Regulation on the law applicable to contractual obligations (Rome I).

The author is of the opinion the newly adopted legal framework for consumer protection under the directive on consumer rights seems to be more predictable especially in terms of supporting consumers with more mandatory information before the conclusion of a contract with a professional as well as a single 14 day withdrawal period for all Member States. However, the level of consumer protection in the purchase of digital content is insufficient and from the perspective of conflict of laws rules for consumer contracts under Rome I, a consumer who actively makes a purchase from a professional from another Member State or a third country cannot expect the special protective rules envisaged in the regime under $C R D$ and Rome I to be applied by default; rather, the general rules come into play.

\section{KEY WORDS}

Consumer contracts, choice of law, Rome I regulation on law applicable to contractual obligations, directive 2011/83 on consumer rights

\section{CONSUMER PROTECTION UNDER THE ROME I REGULATION - AN OVERVIEW}

The Rome I Regulation is a European instrument that offers a heightened level of legal certainty in protecting consumers from the consequences of an

Agata Jaroszek Ph.D., Faculty of Law, Administration and Economy of the University of Wrocław, aajjkk@prawo.uni.wroc.pl. 
adverse contractual choice of law. ${ }^{1}$ The system provides conflict of laws rules harmonized to a minimum standard and offers a 'specific treatment' for consumer contracts with substantive restrictions on party autonomy. ${ }^{2}$ Party autonomy is widely recognized as a general principle of private law. Under Rome I freedom of choice of law determined by the parties applies to all contracts falling within the scope of that instrument (recital 11, Art. 3); however, in case of certain types of contracts the contractual choice is subject to either geographical limitations such as in contracts of carriage (Art. 5), small-risk insurance contracts (Art.7) or substantive limitations of otherwise applicable law (lex causae) such as consumer contracts (Art. 6) and employment contracts (Art. 8). Such limitations stem from the policy approach of the EU: should a professional conclude a contract with a party regarded as being weaker (respectively, a passenger, consumer, policy holder, employee), conflict of law rules that are more favourable to their interests than the general rules shall apply. ${ }^{3}$

In consumer contracts freedom of choice is permitted, but limited. The trader and consumer can choose another applicable law as long as this would not deprive the consumer of the mandatory consumer protection rules available under the consumer's 'home law' (Article 6(1) Rome I). Should the law chosen by the parties provide weaker protection, those consumer law rules which offer lower standards will be superseded by the mandatory rules of the consumer's place of habitual residence. ${ }^{4}$

Under Article 6(2) of Rome I, the consumer's position is strengthened by another policy consideration: the application of mandatory rules of the country where the consumer has his habitual residence that cannot be derogated from by an agreement when the consumer concluded the contract with the professional who pursued his commercial or professional activities in that particular country. ${ }^{5}$ The same protection should be guaranteed if the professional, while not pursuing his commercial or

\footnotetext{
Regulation (EC) No 593/2008 of the European Parliament and of the Council of 17 June 2008 on the law applicable to contractual obligations (Rome I), OJ L 177, 4.7.2008, p. 6.

2 S. C. Symeonides, Party Autonomy in Rome I and II from a Comparative Perspective, in K.B. Brown, D.V Snyder, (eds.), General Reports of the XVIIIth Congress of the International Academy of Comparative Law, Springer Science+Business Media 2011, p. 530-533.

3 This approach is reflected in Recital 23 of Rome I.

4 Directorate-General for Internal Policies Policy Department C: Citizens' Rights and Constitutional Affairs Legal Affairs The Functioning of the CESL within the Framework of the Rome I Regulation - Study.

5 F. Ferrari, S. Leible, Rome I Regulation: The Law Applicable to Contractual Obligations in Europe, Sellier 2009, p. 360-363.
} 
professional activities in the country where the consumer has his habitual residence, directs his activities by any means to that country or to several countries, including that country, and the contract is concluded as a result of such activities. ${ }^{6}$

The main principle that follows from Rome I is that a professional and a consumer can choose another applicable law as long as the choice would not deprive the consumer of the mandatory consumer protection rules in the country where the consumer is habitually resident.

The term of a consumer's habitual residence as a factor connecting a person to a territory and its legal system, thus determining the applicable law to a contract, is not defined in Rome I, nor has it been defined in many jurisdictions. ${ }^{7}$ The habitual residence concept, promoted by the European legislator as a connecting factor providing more legal certainty compared with other classical factors such as nationality and domicile, allows for some flexibility in the scope of defining this term. Thus, the term 'habitual residence' should be construed autonomously, nevertheless showing a close link to the country in question. Judges especially should take into account subjective factors of permanence, namely the fact that a person has been in a given country for some time and intends to stay there for the foreseeable future. ${ }^{8}$

To be precise, Rome I does not define the term 'habitual residence' for natural persons, but it does for companies and other bodies, corporate or unincorporated; Article 19 of the Regulation includes a clear definition of habitual residence based on a single criterion: the place of central administration for companies and other bodies corporate or unincorporated, whereas in case of a natural person acting in the course of his business activity, habitual residence shall be his principal place of

6 Rome I, Recital 25 and Art. 6(1) and (2).

7 For example, the Polish Act of 4 November 2011 on private international law (OJ L Poland No. 80, item 432) does not define this term, leaving this task to legal scholars and case law, although it has also been applied to determine the law applicable to the status of natural persons or family relations.

8 http://www.citizensinformation.ie/en/ (last visited 14 January 2015). 
business. ${ }^{9}$ One single criterion is deemed sufficient for parties to foresee the law applicable to their contract. ${ }^{10}$

The concept of 'directed activity' as a condition for application of the mandatory consumer protection rules available under the law of his habitual residence must be viewed in the light of the objective of the conflict of laws rule and its relation to the development of IT law, especially electronic commerce tools. As it is reflected in Recital 28 of Rome I, the conflict of law rule for consumer contracts should reduce the cost of settling disputes since most of consumer claims involve small sums; secondly, the conflict of law rule designed to protect the consumer should take account of the development of distance-selling techniques. Further on, the same recital makes explicit reference to the joint declaration by the Council and the Commission on Article 15 of Regulation (EC) No 44/2001 of 22 December 2000 on jurisdiction and the recognition and enforcement of judgments in civil and commercial matters that determines jurisdiction over consumer contracts (now Article 17), when the condition of 'directing activity' under Article 15 (1)(c) of Brussels I (now Article 17 (1)(c) of Brussels I bis) is deemed to be fulfilled. ${ }^{11}$ This provision relates to a number of marketing methods, including contracts concluded at a distance, e.g. via the Internet. In the light of growing importance of electronic commerce transactions, the issue of establishing criteria determining when the website by means of

9 Rome I definition of habitual residence art. 19. For discussion of habitual residence as a connecting factor see for example M. Giuliano \& P.Lagarde, Report on the Convention on the Law Applicable to Contractual Obligations, 1980 O.J. (C 282) 1, 20, Commission Green Paper on the Conversion of the Rome Convention of 1980 on the Law Applicable to Contractual Obligations into a Community Instrument and its Modernization, COM (2002) 654 final, O.Lando \& P. Arnt Nielsen, The Rome I Regulation, 45 CMLR 1687, 1699 (2008).

10 Rome I recital 39, unlike Article 60(1) of Regulation (EC) No 44/2001, which establishes three criteria for establishing the domicile of a company or other legal person or association of natural or legal persons: statutory seat, central administration, or principal place of business. Date of end of validity: 09/01/2015; Repealed by Regulation (EU) No 1215/2012 of the European Parliament and of the Council of 12 December 2012 on jurisdiction and the recognition and enforcement of judgments in civil and commercial matters (recast) (now Article 63), OJ L 351, 20.12.2012, p. 1.

11 OJ L 12, 16.1.2001, p. 1. Regulation No 44/2001 repealed by Regulation (EC) No 1215/2012 (OJ L 351, 20.12.2012, p. 1) in force since 10 January 2015. Article 15 1. In matters relating to a contract concluded by a person, the consumer, for a purpose which can be regarded as being outside his trade or profession, jurisdiction shall be determined by this Section, without prejudice to Article 4 and point 5 of Article 5, if: (a) it is a contract for the sale of goods on instalment credit terms; or (b) it is a contract for a loan repayable by instalments, or for any other form of credit, made to finance the sale of goods; or (c) in all other cases, the contract has been concluded with a person who pursues commercial or professional activities in the Member State of the consumer's domicile or, by any means, directs such activities to that Member State or to several States including that Member State,and the contract falls within the scope of such activities. See also, Y. Nishitani, Contracts Concerning Intellectual Property Rights, in: F. Ferrari, S. Leible, Rome I Regulation: The Law Applicable to Contractual Obligations in Europe, p. 72-73. 
which a professional 'directs' his offer of sale of goods or provision of services requires a functional distinction between active and passive websites. The former are deemed to actively promote and offer sales or services in other Member States, while the latter do not offer technological tools for placing orders and serve merely as sources of information about goods and services.

From the text of the joint declaration it follows that 'it is not sufficient for an undertaking to target its activities at the Member State of the consumer's residence, or at a number of Member States including that Member State; a contract must also be concluded within the framework of its activities'. The declaration also states that 'the mere fact that an Internet site is accessible is not sufficient for Article 15 of Brussels I to be applicable, although a factor will be that this Internet site solicits the conclusion of distance contracts and that a contract has actually been concluded at a distance, by whatever means. In this respect, the language or currency which a website uses does not constitute a relevant factor' ${ }^{12}$

For application of consumer protection rules under Article 15 of Brussels I (now Article 17 of Brussels I bis) and Article 6 of Rome I, it is necessary that an Internet site solicits the conclusion of distance contracts and that a contract has actually been concluded at a distance.

The concept of 'directing' commercial or professional activities to the country of the consumer was addressed by the European Court of Justice in joined cases C 585/08 and C 144/09 Peter Pammer and Hotel Alpenhof GesmbH upon the interpretation of Article 15(1)(c) and (3) of Brussels I, and among other things establishing the criteria that constitute web accessibility to potential buyers or service users in other Member States. The Court held that the mere use of a website by a trader with a view to engaging in trade does not mean that its activity is 'directed to' other Member States. It considered that it should be ascertained whether, before the conclusion of any contract with the consumer, it is apparent from this website and the trader's overall activity that the trader envisaged doing business with consumers domiciled in one or more Member States, including the Member State of that consumer's domicile, in the sense that it was minded to

Council of the European Union, Proposal for a Council Regulation on jurisdiction and the recognition and enforcement of judgments in civil and commercial matters (Brussels I) 14139/00 JUSTCIV 137 http://euzpr.eu/eudocs/01prozessr/10zivilhandelsr/10brusselivo/brusselivo-172-rat_1413900_en.pdf (last visited on 21 April 2015) . 
conclude a contract with them. ${ }^{13}$ This judgment sets out a number of criteria for establishing whether a website is 'directed' at a specific Member State, such as the use of different languages or currencies on the website. ${ }^{14}$ In any event, it is for the national courts to ascertain whether such evidence exists, and the list of suitable evidence given by the Court is not exhaustive. ${ }^{15}$

If a consumer contract does not satisfy the conditions of Article 6, then the process of linking the contract with a legal system will be carried out under the rules of Art. 3 (freedom of choice) and Art. 4 of the Rome I Regulation (applicable law in the absence of choice). In the case of the sale of goods, a contract shall be governed by the law of the country where the seller has his habitual residence, while in case of the provision of services such a contract shall be governed by the law of the country where the service provider has his habitual residence. ${ }^{16}$ A consumer who meets the conditions of Article 6 is protected by all the mandatory provisions of his/her country of habitual residence, whereas one who does not meet the conditions of Article 6 is nevertheless protected by the overriding mandatory provisions of his/her country of habitual residence on the basis of Article 9 (overriding mandatory rules) of the Rome I Regulation. This provision allows judges on a discretionary basis to invoke a rule of public policy of the forum or of the place of performance that can be applied regardless of the choice of otherwise applicable law. The application of Article 9 as well as public policy of the forum (Art. 21 Rome I) is too complex and would require a more elaborate discussion. For the sake of clarity the issues are only signalled as important and potentially putting restrictions on party autonomy in choice of law in general, and for consumer contracts particularly when the law of a third country chosen by the parties comes into play.

Article 9 of Rome I provides a definition of the overriding mandatory rules, referring to respect for provisions which are regarded as crucial by a country for safeguarding its public interests; these are understood to

13 C- 585/08 Peter Pammer and C-144/09 Alpenhof, judgment of 7 December 2010, summary available at: http://ec.europa.eu/dgs/legal_service/arrets/08c585_en.pdf (last visited 20 April 2015).

14 OJ C 44, 21.2.2009 OJ C 153, 4.7.2009, See paragraphs 92 and 93 of the Judgment.

15 However, the ECJ"s decision was met with some critical comments as far as long-term impact on cross-border e-commerce within the European Union, for example see D.J.B. Svantesson, Pammer and Hotel Alpenhof - ECJ decision creates further uncertainty about when e-businesses "direct activities" to a consumer's state under the Brussels I Regulation, 27 Computer Law \& Security Review, Issue 3/2011, pages 298-304.

16 Art. 4(1a) and (1b) of Rome I. 
include its political, social or economic organization, and their salience is such that they are applicable to any situation falling within their scope irrespective of the law otherwise applicable to the contract under the Rome I Regulation. Paragraph 2 points out to the application of internationally mandatory rules of forum (lex fori) that may defeat either a contractual or a judicial choice of another law. Under Art 9(3) of the Rome I Regulation, the possibility of applying 'overriding mandatory rules' is restricted to those of the law of the country of the performance of the contract which render the contract unlawful. The effect is given to internationally mandatory rules of the country of performance of the obligation; there is no mention of the application of these rules of another state. ${ }^{17}$ To briefly describe the function (mechanism) of Article 9, an offending provision of the law chosen by the parties, especially those to a consumer contract, will be replaced by the relevant provision of the mandatory law otherwise applicable. The public interest of the state is emphasized.

By virtue of Article 21 the offending provision of the chosen law will be invalidated as contrary to the public policy of the forum and an alternative will be provided by default; public order will be applicable, and the offending provision - and more likely the whole contract - will be void. ${ }^{18}$

As it was mentioned earlier, in the case of certain types of consumer contracts the law of the country where the consumer has his habitual residence applies when parties choose another law. Therefore, a choice of law agreement cannot deprive a consumer of the protection of the mandatory rules of the state of the lex causae (in practice this will be the country where the consumer has his habitual residence).

In principle, as far as consumer rights are concerned, Rome I offers protection under the law of the country of habitual residence to "passive consumers". This limitation to 'passive consumers' has been criticised by some commentators especially in light of the growing importance of electronic commerce and mobile commerce. This distinction should no longer be considered for the application of the consumer's 'home law'

17 On February 25, 2015, the German Federal Labour Court referred three questions relating to the interpretation of Art. 9 and Art. 28 Rome I Regulation to the CJEU. One question asked was whether Art. 9(3) Rome I Regulation actually prohibits the application of overriding mandatory provisions which are neither overriding mandatory provisions of the lex fori nor of the place of performance. See more comments L. Günther, German Federal Labour Court on Foreign Mandatory Rules and the Principle of Cooperation among EU Member States at: http://conflictoflaws.net/2015/german-federal-labour-court-on-foreign-mandatory-rulesand-the-principle-of-cooperation-among-eu-member-statesbecomes crucial.

18 G. van Calster, European Private International Law, Oxford 2013, 3.2.8. 
under Article 6 of Rome I due to the fact of integration of national markets, and secondly due to the emergence of new forms of e-commerce, e.g. social commerce where buyers harness the power of social networks that consist of a large number of people who are potential generators of content and are also a significant source of information about goods and services. In the near future social networks will become a commercial space that provides a unique shopping experience characterized by strong collaboration and social interaction between merchants and consumers. ${ }^{19}$

\section{THE RELATION BETWEEN THE SCOPE OF THE DIRECTIVE ON CONSUMER RIGHTS (CRD) AND ROME}

\section{I.}

Turning now to the main topic of this paper, which is the relation between the scope of the Directive on Consumer Rights (CRD) and Rome I.

Firstly, the purpose of adoption of Directive $2011 / 83 / \mathrm{EU}^{20}$ on consumer rights is modernization of consumer law in the narrow area of distance and off-premises contracts, as well as contracts including digital content not supplied on a tangible medium (downloads, etc.), along with some minor amendments to Directive 93/13 on unfair terms and Directive 99/44 on consumer sales. As pointed put by several authors, the Directive is thus somewhat eclectic in character, covering off-premises and distance sales contracts while also containing general pieces of consumer legislation which it refers to as "Other Consumer rights" ${ }^{21}$ It should also be noted that not all provisions are mandatory and Member States are left with a number of optional provisions permitting non-application of the Directive or not to maintain or introduce corresponding national provisions. ${ }^{22}$

19 J. Chtioui,T. Abdellatif, and T. Majd, A Semantic Study to Identify the Dimensions of the Purchasing Decision Process in the Social Commerce (July 7, 2014). Available at SSRN: http://ssrn.com/abstract=2501276 or http://dx.doi.org/10.2139/ssrn.2501276

20 The CDR amends Council Directive 93/13/EEC and Directive 1999/44/EC of the European Parliament and of the Council and repealing Council Directive 85/577/EEC and Directive 97/7/EC of the European Parliament and of the Council.

${ }^{21}$ P. Giliker, The Transposition of the Consumer Rights Directive into UK Law: Implementing a Maximum Harmonisation Directive. (November 12, 2014). Available at SSRN: http://ssrn.com/abstract=2523330 or http://dx.doi.org/10.2139/ssrn.2523330

22 Articles 3(4), 5(3), 5(4), and 6(7) of the CRD: off-premises contracts for which the payment to be made by the consumer does not exceed EUR 50, non-application of information requirements to contracts other than distance and off-premises contracts which involve dayto-day transactions and which are performed immediately at the time of their conclusion or left with the discretion to maintain or introduce in their national law language requirements regarding the contractual information, so as to ensure that such information is easily understood by the consumer distance and off-premises contracts. Articles 3(4), 5(3), 5(4), and $6(7)$, CRD. 
In the Commission's opinion, the Directive on consumer rights is now the main consumer protection instrument for online services, and the effects of implementation of the CRD are expected to boost consumers' confidence in cross-border transactions, including e-commerce sector; indeed, the effectiveness of its provisions will be tested in the forthcoming years.

The policy approach of the CRD is to refrain from interfering in the application of the conflict of law rules of the Rome I Regulation (recital 10 of CRD), thus avoiding problems such as those arising from the E-commerce Directive $^{23}$ or from clauses included in previous consumer directives such as Council Directive 93/13/EEC of 5 April 1993 on unfair terms in consumer contracts $^{24}$, Directive 1999/44/EC of the European Parliament and of the Council of 25 May 1999 on certain aspects of the sale of consumer goods and associated guarantees ${ }^{25}$, and Directive 97/7/EC of the European Parliament and of the Council of 20 May 1997 on the protection of consumers in respect of distance contracts (Directive on Distance Selling) ${ }^{26}$

The problems identified concern a uniform application of the Community law, mainly conflict of law rules stemming from these directives; to some extent, the Directive on Distance Selling and its implementing measures overlapped with the E-commerce Directive, which led to inconsistent approaches regarding information requirements between the E-commerce Directive and the two Directives on Distance Selling (including Directive 2002/65/EC on distance marketing of consumer financial services of 23 September $2002^{27}$ ) or divergent information requirements in different consumer protection directives in the contract law sphere. ${ }^{28}$

The E-commerce Directive was founded on the principles of home country control and mutual recognition. Under the E-commerce Directive the law of the state where the service provider is established shall apply concerning the requirements that the service provider has to comply with. In legal writing there was extensive debate as to whether the Directive

${ }^{23}$ Directive 2000/31/EC of the European Parliament and of the Council of 8 June 2000 on certain legal aspects of information society services, in particular electronic commerce. OJ L $178 / 1,17.7 .2000$.

${ }^{24}$ OJ L 95, 21.4.1993, p. 29.

25 OJ L 171, 7.7.1999, p. 12.

${ }^{26}$ OJ L 144, 4.6.1997, p. 19. Consumers' rights in electronic commerce, Jurisdiction and applicable law on cross-border consumer contracts, BEUC/X/019/2000.

27 OJ L 271 of 9.10.2002, p. 16.

28 A More Coherent European Contract Law An Action Plan COM(2003) 68 final. 
established a particular choice of law rule for e-commerce, designating the law of the service provider as applicable - the so-called country of origin principle (Articles 3 and 1(4)). Hellner's approach seems to support the view that the E-commerce directive not only sets certain limitations to the application of the choice of law, but also actually has an effect on the question of which law is applicable. The author concludes that the Ecommerce Directive makes the rules of the home country of the service provider internationally mandatory and thus applicable irrespective of what law is applicable to the contract or tort, etc. ${ }^{29}$

The 'country of origin' rule neither covers the freedom of parties to choose the law applicable to their contract that would be determined according to the conflict of laws rules of Rome I, nor contractual obligations concerning consumer contracts. Such obligations include "information on the essential elements of the content of the contract, including consumer rights, which have a determining influence on the decision to contract." ${ }^{\prime 30}$

Article 6(2) of Directive 93/13 on unfair contractual terms seeks in certain cases to avert the risk of depriving consumers of the Community minimum standards of protection resulting from choice of law of a non-EU member state (third country) as applicable to a contract having a 'close connection' with the territory of a Member State. The corresponding provisions to Article 6(2) of Directive 93/13 are found in Article 7(2) of Directive 1999/44/EC on certain aspects of the sale of consumer goods and associated guarantees. In the view of some commentators, Article 7(2) does not indicate governing law, but rather serves the purpose of excluding the application of the law of a non-EU state. ${ }^{31}$ The same approach was taken in Article 12 (2) of Directive 97/7 on distance selling (repealed by the CRD).

Protection of weaker parties, as a part of public policy, is pursued by the additional application of provisions of the 'home law' of a weaker party i.e. the consumer. Such a conclusion can be inferred from the wording of Article 3(4) of Rome I, which protects consumer contracts (alongside other contracts) under mandatory rules introduced by EU law, which, as part of

${ }^{29}$ M. Hellner, 'The Country of Origin Principle in the E-commerce Directive - A Conflict with Conflict of Laws?' (2004) 12 European Review of Private Law, Issue 2, pp. 206-213.

${ }^{30}$ M. F. Kightlinger, A Solution to the Yahoo! Problem? The EC Ecommerce Directive as a Model for International Cooperation on Internet Choice of Law, 24 Mich. J. Int'1 L. 719 (2003), p. 736.

31 C. M, Bianca, S. Grundmann, E.U. Sales Directive, Intersentia (2002), p. 259. 
the law of the forum, will be applied in addition to the law chosen by the parties (primarily a third country's law). ${ }^{32}$

The CRD unequivocally declares itself to be a EU-wide imperative act ${ }^{33}$; the wording of Art. 25 states that:

If the law applicable to the contract is the law of a Member State, consumers may not waive the rights conferred on them by the national measures transposing this Directive. Any contractual terms which directly or indirectly waive or restrict the rights resulting from this Directive shall not be binding on the consumer.

In addition, Recital 10 provides that:

The consumer should not be deprived of the protection granted by this Directive. Where the law applicable to the contract is that of a third country, Regulation (EC) No 593/2008 should apply, in order to determine whether the consumer retains the protection granted by this Directive.

According to some commentators, neither Article 25 nor, for example, Article 6(2) of the Unfair Terms Directive provide any protection in case the consumer contracts with a professional established in a third country. Under the Rome I Regulation a similar problem, however, has been identified when it comes to affording protection under the law of the consumer's habitual residence in respect of on-premises purchases when travelling abroad; in these cases the contract is subject to a foreign law and a different level of protection. ${ }^{34}$ On the other hand, the restriction on choice of law in case of consumer contracts under Article 6(2) of Rome I would prevent the consumer from benefiting from the chosen law when it occurs that the third country law offers a higher level (standard) of consumer protection.

This short overview of issues at the junction of consumer law and private international law demonstrate the complexity of the current situation; the narrow scope of harmonization efforts undertaken in the CRD will not solve 'old problems' which have been under discussion since the adoption of the first 'consumer directives' and the Rome I.

32 V. Behr, Rome I Regulation a-Mostly-Unified Private International Law of Contractual Relationships within-Most-of the European Union, 29 Journal of Law and Commerce No 2/2011, p. 267.

33 G. van Calster, European Private International Law, Oxford 2013, 3.2.6.

34 J. J. Kuipers, EU Law and Private International Law (2012), p. 196-197. 


\subsection{STATISTICS AND FACTS ABOUT CROSS-BORDER PURCHASES}

Facts and statistics, however, have shown that the reality of cross-border purchases over the preceding decade, including in the e-commerce sector, has been one of rather sluggish growth of cross-border consumer transactions, including those conducted on-line.

To start with a general observation, a study of obstacles and proposals for policy options to adapt the consumer acquis to the new challenges posed by social transformations and developments in ICT (referred hereinafter as Impact Assessment Report) concluded that consumers' confidence in crossborder shopping is affected by factors of a practical nature (such as language or geographical proximity), as well as insufficient knowledge of their rights or difficulties with their enforcement. As the Commission indicated, "the shortfalls in consumer confidence have a number of causes including the insufficient knowledge by consumers of their rights, their perception that they would be less protected if they buy from foreign traders and that enforcement and mediation would be more difficult to carry out abroad". ${ }^{35}$

According to a Eurobarometer report published in June 2013: a) in 2012 the proportion of Internet shoppers almost doubled, compared to $27 \%$ in 2006, b) $15 \%$ of EU consumers have now made at least one online purchase from a seller/provider in another EU country in the past 12 months, compared with just $6 \%$ in 2006, c) a significant increase has also been observed in EU consumers who have made Internet purchases from a seller or provider located outside the EU, $8 \%$ (up from $3 \%$ in 2006), d) EU consumers are considerably more likely to have purchased online from a seller/provider based in their own country $(47 \%)$ than from one located in another EU country (15\%). In the report, a preference has been observed for purchases via the Internet both domestically and cross-border among consumers who have Internet access at home, as well as a preference for making online purchases from sellers or providers based in the respondent's own country. The results reflect the attitudes of both the consumer and business (trader, professional, seller, service provider)

Commission Staff Working Document accompanying the proposal for a directive on consumer rights Impact Assessment Report pt 1.1. According to $62 \%$ of consumers who had not made a cross-border distance purchase, fears about fraud had put them off. 5th Consumer Scoreboard and Flash Eurobarometer 299. 'Consumer attitudes towards crossborder trade and consumer protection',2011. 
sides. ${ }^{36}$ As another Eurobarometer report has stated, only 29\% of traders know where to look for information or advice on the consumer protection legislation in force in other European countries. Additionally, $72 \%$ of distance sellers do not know the exact length of the cooling off period for distance sales in their own country. ${ }^{37}$ Many businesses think that it is too complicated or too risky to sell online or expand their activity to include cross-border sales. ${ }^{38}$

On the other hand, in October 2011, the ECC-Net Mystery Shopping Report $^{39}$ found that cross-border online shopping does not create more problems than buying from a domestic trader. The delivery rate is high $94 \%$ of orders - and in $99 \%$ of cases the items delivered are in conformity with the order. However, the number of online vendors who engage in cross-border transactions is still limited. Of the total number of sites originally selected, $60 \%$ did not offer cross-border ordering. ${ }^{40}$

It is not surprising to conclude that that EU citizens prefer making online purchases from a local seller or provider; traditionally, the number of cases related to cross-border disputes was not high, but the development of ecommerce selling techniques has added to these cases. While, in consideration of the fact that the number of online cross-border consumer sales has tripled since 2006 compared to 2012, there is a growing volume of such cases, the number of EU consumers that have made online purchases in another EU Member State or a third country remains small.

The system of protection promoted in the CRD is based on the idea that the consumer is in a weaker position vis-à-vis the seller or supplier, as regards both his bargaining power and his level of knowledge of legal and economic issues surrounding commercial transactions. ${ }^{41}$ The rationale of consumer law is to provide mandatory protection to the consumer as the weaker party to the contract. Consumer contracts are typically contracts of

36 Consumer attitudes towards cross-border trade and consumer protection Flash EB Series \#358 June 2013.

37 Source: Flash Eurobarometer 300, retailers' attitudes towards cross-border trade and consumer protection, 2011.

38 Commission Communication to the European Parliament, the Council, the Economic and Social Committee and the Committee of the Regions A coherent framework for building trust in the Digital Single Market for e-commerce and online services, COM(2011) 942 final.

${ }_{39}$ Mystery Shopping Report ECC-Net 2011.

40 The European Online Marketplace Consumer complaints 2010-2011 Report ECC-Net 2012.

${ }^{41}$ Judgement in Walter Vapenik v Josef Thurner, C 508/12, paragraphs 26-31 (see, inter alia, Case C 618/10 Banco Español de Crédito [2012] ECR, paragraph 39; Case C 92/11 RWE Vertrieb [2013] ECR, paragraph 41; and Case C 488/11 Asbeek Brusse and Man Garabito [2011] ECR, paragraph 31). 
"adhesion", meaning the business imposes them in a standardised form. The consumer is not on a level playing field with the business and cannot negotiate the terms of the contract. ${ }^{42}$

Protective measures in force when the surveys and reports cited above were prepared proved to be reliable in the domestic marketplace, whereas the benefits that could be drawn from a truly EU-wide electronic marketplace still require better legislation, more well-adapted technological tools for secure payments, as well as awareness campaigns and training for consumers and internet traders.

The conflict of law rule for consumer contracts as provided for in Art. 6 of the Rome I has been criticized by businesses who argue that if a trader wishes to sell abroad he is confronted with 27 regimes, including national laws implementing consumer directives that in some aspects have different protective measures/standards of protection. ${ }^{43} \mathrm{~A}$ trader needs to know and assess the national law of each Member State.

It is worth mentioning that in the Impact Assessment accompanying the proposal for a directive on consumer rights (CRD), the Commission acknowledged that Rome I had caused problems for business in determining the appropriate level of consumer protection that needed to be respected in each transaction. ${ }^{44}$ During the consultation process, business organizations supported the Internal Market clause that would derogate from Rome I allowing entities engaged in cross-border trading to freely choose the law applicable to the contract. Such an Internal Market clause could have taken the form of a mutual recognition clause or of a clause on the country of origin principle for aspects falling within the scope of a future CRD and not subject to full harmonisation. A mutual recognition clause would give Member States the possibility to introduce stricter rules in their national law, but would not entitle a Member State to impose its own stricter requirements on businesses established in other Member States in a way which would create unjustified restrictions to the free movement of goods or to the freedom to provide services. A clause based on the

${ }^{42}$ BEUC Common European Sales Law. The Commission's proposal for a regulation (COM(2011) 635 final). BEUC preliminary position .

43 EC Consumer Law Compendium (red. H. Schulte-Nölke, współpraca Ch. Twigg-Flesner, M.Ebers,

http://ec.europa.eu/consumers/rights/docs/consumer_law_compendium_comparative_anal ysis_en_final.pdf

44 http://www.publications.parliament.uk/pa/ld200809/ldselect/ldeucom/126/12606.htm (last visited 21 April 2015). 
country of origin principle would give Member States the possibility to introduce stricter consumer protection rules in their national law, but businesses established in other Member States would only have to comply with the rules applicable in their country of origin.

On the other hand, consumers would be subject to different levels of protection when they buy from foreign traders. The option would create problems for courts and mediators who would have to apply a foreign law; it would not improve the quality of the legislation and would be inconsistent with the approach followed by the Rome I Regulation. Proposals for such a solution were torpedoed. ${ }^{45}$

\section{CONCLUDING REMARKS}

It should be also noted that protection of the weaker party under private international law is not one of the main reasons why the growth of online consumer transactions with traders from different Member States or third countries is still relatively low. Obviously there may be a risk of overlapping application of different mandatory rules with their origins in both private and public law including conflict of law rules laid down in Rome I, especially conflict of law rules stemming from the consumer directives that were not subject to full harmonization. Even if there are legal remedies provided for cross-border disputes, consumers often decide to give up their claims due to the small sums involved. It is worth mentioning the ECLG report on "Jurisdiction and applicable law in cross-border consumer complaints" published in 1998, in which the authors observed that "under the current framework a cross-border litigation has potential positive economic effects for the consumer only above a value in litigation of 2000 Euro". Cross-border consumer disputes call rather for the further development of efficient Alternative Dispute Resolution (ADR) bodies and online platforms than searching redress in costly and time consuming court procedures. ${ }^{46}$

The level of consumer protection in the purchase of digital content is insufficient and from the perspective of conflict of laws rules for consumer contracts under Rome I, a consumer who actively makes a purchase from a professional from another Member State or a third country cannot expect

45 Impact Assessment part 1, see footnote 35.

46 See especially mechanisms adopted under Directive on consumer ADR (OJ L 165, 18.6.2013, p. 63) and Regulation on consumer ODR (OJ L 165, 18.6.2013, p. 1). 
the special protective rules envisaged in the regime under CRD and Rome I to be applied by default; rather, the general rules come into play.

A beneficial step would be the initiation of educational campaigns for consumers wishing to enter into contracts (in particular online contracts) with professionals established in another Member State or a third country, informing consumers about their new rights especially when buying digital content or ordering online services such as dating or gaming. What is more important to consider is that a decision on contracting with a professional from a third country where the choice of law was not agreed upon, particularly in the online environment where technological tools enable the conclusion of contracts within seconds or minutes, should be made with some degree of caution and care in order to minimize the risk of needing to seek legal protection and redress.

\section{LIST OF REFERENCES}

Asbeek Brusse and Man Garabito, C-488/11 [2011] ECR.

Behr, V, 'Rome I Regulation a-Mostly-Unified Private International Law of Contractual Relationships within-Most-of the European Union', Journal of Law and Commerce, No 2/2011.

Bianca, CM, Grundmann, S 2002, E.U. Sales Directive, Intersentia.

Citizens Information 2015, Citizens Information, Dublin, viewed 14. January 2015, <http://www.citizensinformation.ie/en/>.

Commission Communication to the European Parliament, the Council, the Economic and Social Committee and the Committee of the Regions 2012, European Commission, viewed 7. June 2015, $<$ http://ec.europa.eu/internal_market/ecommerce/docs/communication20 12/COM2011_942_en.pdf >.

Commission Green Paper on the Conversion of the Rome Convention of 1980 on the Law Applicable to Contractual Obligations into a Community Instrument and its Modernization, COM 2002. 
Commission Staff Working Document accompanying the proposal for a directive on consumer rights 2008, Impact Assessment Report, Commission of the European Communities, viewed 7. June 2015, $<$ http://www.parliament.bg/pub/ECD/75765SEC_2008_2544_EN_DOCU MENTDETRAVAIL_f.doc>.

Commission Staff Working Document accompanying the proposal for a directive on consumer rights 2008, Impact Assessment Report, Commission of the European Communities, viewed 7. June 2015, $<$ http://www.parliament.bg/pub/ECD/75765SEC_2008_2544_EN_DOCU MENTDETRAVAIL_f.doc>.

Common European Sales Law The Commission's proposal for a regulation (COM(2011) 635 final) 2012, preliminary position, BEUC, viewed 7. June 2015, <http://www.beuc.eu/publications/2012-00202-01-e.pdf>.

Computer Law \& Security Review, vol. 27, no. 3.

Consumer attitudes towards cross-border trade and consumer protection 2011, Analytical report, European Commission, viewed 7. June 2015, $<$ http://ec.europa.eu/public_opinion/flash/fl_299_en.pdf >.

Consumer attitudes towards cross-border trade and consumer protection 2011, Analytical report, European Commission, viewed 7. June 2015, $<$ http://ec.europa.eu/public_opinion/flash/fl_299_en.pdf >.

Consumer attitudes towards cross-border trade and consumer protection 2013, Report, European Commission, viewed 7. June 2015, $<$ http://ec.europa.eu/public_opinion/flash/fl_358_en.pdf>.

Consumers' rights in electronic commerce, Jurisdiction and applicable law on cross-border consumer contracts, BEUC/X/019/2000. 
Council of 12 December 2012 on jurisdiction and the recognition and enforcement of judgments in civil and commercial matters (recast) (now Article 63), OJ L 351, 20. December 2012.

Council of the European Union, Proposal for a Council Regulation on jurisdiction and the recognition and enforcement of judgments in civil and commercial matters (Brussels I) 2000, proposal, Council of the European Union, EU, viewed 21. April 2015, $<$ http://euzpr.eu/eudocs/01prozessr/10zivilhandelsr/10brusselivo/brussel ivo-172-rat_14139-00_en.pdf>.

Directive 2000/31/EC of the European Parliament and of the Council of 8 June 2000 on certain legal aspects of information society services, in particular electronic commerce.

Directive on consumer ADR, OJ L 165, 18. June 2013.

Directorate General for Internal Policies Policy Department C 2012, Citizens' Rights and Constitutional Affairs Legal Affairs The Functioning of the CESL within the Framework of the Rome I Regulation - Study, European Parliament, viewed 7. June 2015, $<$ http://www.europarl.europa.eu/webnp/webdav/site/myjahiasite/users/ malfons/public/JURI\%202012/pe462477_en.pdf>.

EU Consumer Rights Directive: getting it right - European Union Committee Contents 2009, European Union, viewed 7. June 2015, $<$ http://www.publications.parliament.uk/pa/ld200809/ldselect/ldeucom/1 26/12606.htm>.

European Commision 2011, C-585/08 Peter Pammer and C-144/09 Alpenhof, judgment of 7 December 2010, Summaries of important judfments, viewed

20.

April 2015, $<$ http://ec.europa.eu/dgs/legal_service/arrets/08c585_en.pdf $>$. 
F Ferrari, S.Leible (eds), Rome I Regulation: The Law Applicable to Contractual Obligations in Europe.

Ferrari, F, Leible, S 2009, Rome I Regulation: The Law Applicable to Contractual Obligations in Europe, Sellier.

Giliker, P, The Transposition of the Consumer Rights Directive into UK Law: Implementing a Maximum Harmonisation Directive, November 12, 2014, viewed 7. July 2015, <http://ssrn.com/abstract=2523330>.

Giuliano, M \& Lagarde, P 1980, 'Report on the Convention on the law applicable to contractual obligations', Official Journal C 282, 31 October.

Günther, L, ' German Federal Labour Court on Foreign Mandatory Rules and the Principle of Cooperation among EU Member States', 25 April, viewed 7. June 2015, <http://conflictoflaws.net/2015/germa-federallabour-court-on-foreign-mandatory-rules-and-the-principle-ofcooperation-among-eu-member-states $>$.

Hellner, M 2004, 'The Country of Origin Principle in the E-commerce Directive - A Conflict with Conflict of Laws?', European Review of Private Law, vol. 12, no. 2.

Chtioui, Abdellatif and Majd, A Semantic Study to Identify the Dimensions of the Purchasing Decision Process in the Social Commerce, 7 July, 2014, viewed 7. July 2015, <http://ssrn.com/abstract=2501276>.

intBanco Español de Crédito, C-618/10 [2012] ECR.

Kightlinger, MF 2003, 'A Solution to the Yahoo! Problem? The EC Ecommerce Directive as a Model for International Cooperation on Internet Choice of Law', Mich. J. Int'l L., vol. 719, no. 24.

Kuipers, JJ 2012, EU Law and Private International Law.

Lando, O \& Nielsen, PA 2008, The Rome I Regulation, 45 CMLR. 
Official Journal of the European Union 2003, 'A More Coherent European Contract Law An Action Plan COM', C63/1.

OJ C 44, 21.2.2009 OJ C 153, 4. July 2009.

OJ L 12, 16.1.2001, p. 1. Regulation No 44/2001 repealed by Regulation (EC) No 1215/2012 (OJ L 351, 20.12.2012).

OJ L 144, 4. June 1997.

OJ L 171, 7. July 1999.

OJ L 178/1, 17. July 2000.

OJ L 271 of 9. September 2002.

OJ L 95, 21. April 1993.

Online cross-border mystery shopping - State of the e-union 2011, European Consumer Centres Network, viewed 7. June, $<$ http://ec.europa.eu/consumers/ecc/docs/mystery_shopping_report_en.p $\mathrm{df}>$

Polish Act of 4 November 2011 on private international law (OJ L Poland No. 80, item 432).

Regulation (EC) No 593/2008 of the European Parliament and of the Council of 17 June 2008 on the law applicable to contractual obligations (Rome I), OJ L 177, 4. July 2008.

Regulation on consumer ODR, OJ L 165, 18. June 2013.

Repealed by Regulation (EU) No 1215/2012 of the European Parliament and of the

Rome I, Art. 4(1a) and (1b).

Rome I, definition of habitual residence, art. 19.

Rome I, Recital 25 and Art. 6(1) and (2).

Rome I, recital 39, unlike Article 60(1) of Regulation (EC) No 44/2001.

RWE Vertrieb, C-92/11 [2013] ECR. 
Schulte-Nölke et al. 2008, EC Consumer Law Compendium, Universität Bielefeld, viewed $7 . \quad$ June 2015, $<$ http://ec.europa.eu/consumers/archive/rights/docs/consumer_law_com pendium_comparative_analysis_en_final.pdf>.

Symeonides, SC 2011, 'Party Autonomy in Rome I and II from a Comparative Perspective', in KB Brown, DV Snyder (eds), GeneralReports of the XVIIIth Congress of the International Academy of Comparative Law, Springer Science+Business Media.

The CDR amends Council Directive 93/13/EEC and Directive 1999/44/EC of the European Parliament and of the Council andrepealing Council Directive 85/577/EEC and Directive 97/7/EC of the European Parliament and of the Council.

The European Online Marketplace Consumer complaints 2010-2011 2012, European Consumer Centres ' Network, viewed 7. June 2015, $<$ http://ec.europa.eu/consumers/ecc/docs/e-commerce-report2012_en.pdf>.

van Calster, G 2013, European Private International Law, Oxford. van Calster. G 2013, European Private International Law, Oxford. Walter Vapenik v Josef Thurner, C-508/12. 